\title{
Highlights on Evidence-Based Treatment Strategies for COVID-19: a Review
}

\author{
Snigdha Bhardwaj 1,*(D), Ashutosh Tiwari ${ }^{1(D)}$ \\ ${ }^{1}$ I.T.S College of Pharmacy, Murad Nagar, Ghaziabad, U.P. (201206), India, tiwariashugar@ gmail.com (A.T.); \\ *Correspondence: snigs.16@gmail.com;
}

Received: 4.04.2020; Revised: 30.06.2020; Accepted: 1.07.2020; Published: 7.07.2020

\begin{abstract}
: $21^{\text {st }}$ century is considered a well-modernized era, but recently a new public health emergency triggered by Severe Acute Respiratory Syndrome Coronavirus-2 (SARS-CoV-2) with the emergence of treatment therapy globally. WHO named it Covid-19 on February 11, 2020, and announced this rapidly spreading corona outbreak a pandemic on March 11, 2020. Currently, there is no known specific vaccine or drug to treat COVID-19. The Coronavirus was first noticed in Wuhan Hubei city of China, in December 2019. COVID-19 originated from an animal source, thus named SARS-CoV-2 that causes mild to severe illness from the common cold to diseased conditions such as Severe Acute Respiratory Syndrome (SARS) \& the Middle East Respiratory Syndrome (MERS). Various key proteins as targets have been identified, which are responsible for its virulence and cause infections in humans. Since it has been started, much research has been conducted and still going on to develop a suitable candidate to inhibit its virulence targeting its key protein targets with in-silico docking studies. This review highlights the viral introduction, its genome, spike protein interaction WHO guidelines and current treatment or drugs, and in-silico docking studies related to SARS-CoV-2.
\end{abstract}

Keywords: SARS-CoV-2; COVID-19; pandemic; MERS (Middle East Respiratory Syndrome); SARS (Severe Acute Respiratory Syndrome);in-silico docking.

(C) 2020 by the authors. This article is an open-access article distributed under the terms and conditions of the Creative Commons Attribution (CC BY) license (https://creativecommons.org/licenses/by/4.0/).

\section{Introduction}

Nowadays, the novel Coronavirus 2019 (SARS-CoV-2) is a new infection that affects human life very badly. COVID-19 is believed to develop in the wet market of Wuhan, China, and has dangerous effects in all over the world since December 2019 [1]. When the situation becomes bad worldwide, then on January 31, 2020, the World Health Organization (WHO) declared it a global emergency. On February 24, 2020, there were total 80,239 cases, and 2700 deaths reported all over the world [2]. Before Covid-19, the world has faced global pandemic infectious disease Severe Acute Respiratory Syndrome Coronavirus (SARS-CoV) in the year 2002-2003 and (the Middle East Respiratory Syndrome Coronavirus (MERS-CoV) in the year 2011. SARS-CoV-2 has the same Genomic Sequence, but in SARS-CoV \& MERS-CoV have different Genome Composition [3]. The reason behind the coronavirus infections is considered to be bats, palm cats, and wet market in China, resulting in acute respiratory infections in people of china and cause many deaths [4]. The first case of clinical features with 41 patients infected from SARS-CoV-2 was reported on January 2, 2020, and among those, 28 patients were found to be Non-ICU cases while 13 patients were ICU cases. The primary manifestations of Covid19 infection included fever, cough, dyspnea, fatigue, sputum production, headache, and diarrhea [5]. In India, 3 cases are reported until March 2, 2020. On March 5, 2020, cases are 
reported in cities like Jaipur, Delhi, Agra with Italian tourists. Through them, many contact persons are infected. One case in Indian who lastly traveled from Vienna is corona infected goes to a birthday party in which many children are invited to the hotel. Many persons who have contact with infected persons all are quarantined for 14 days [6].

\section{The novel Coronavirus 2019 (SARS-CoV-2)}

SARS-CoV-2 is a solo-stranded RNA virus ranges from 60- $140 \mathrm{~nm}$ size in diameter and looks like a crown structure. That's why named Coronavirus [7]. SARS-CoV-2 belongs to the Coronaviridae family and Nidovirales order. The virus has various genera, namely $\alpha-$ Coronavirus, $\beta$-Coronavirus, $\gamma$ - Coronavirus, $\delta$-coronavirus. The morphologically, SARSCoV-2 appears crown-like as it has outer projections on the outer surface (Spike Protein) $[8,9]$. The spherical to pleomorphic envelop bears club-shaped glycoprotein projections on its outer surface (as represented in Fig. 1). The size of the virus is minute, ranging from 80-120 nm, and it consists of the largest RNA genome among all known RNA viruses. Coronavirus genetic material is susceptible to continuous recombination within the genome resulting in new strains of human Coronavirus. Based on various reports, SARS-CoV-2 contains genomic material, which is approx 79 percent homogeneous with previously known human coronaviruses [10,11]. Presently, seven strains of human Coronavirus are known, namely 229E \& NL63 ( $\alpha$ coronaviruses); OC43, HKU1, MERS-CoV, SARS-CoV, and SARS-CoV-2 ( $\beta$-coronaviruses). All of these viruses cause upper and lower respiratory tract infections. Among all strains, three strains are highly pathogenic, namely SARS-CoV, MERS-CoV, and SARS-CoV-2. The SARS-CoV and MERS-CoV cause acute lung injury and acute respiratory syndrome, followed by pulmonary failure resulting in a fatality. These viruses were believed to transmit the infection to animals only before the SARS-CoV outbreak in Guangdond, China (2003), and MERS-CoV in Saudi Arabia (2012) [12,13].

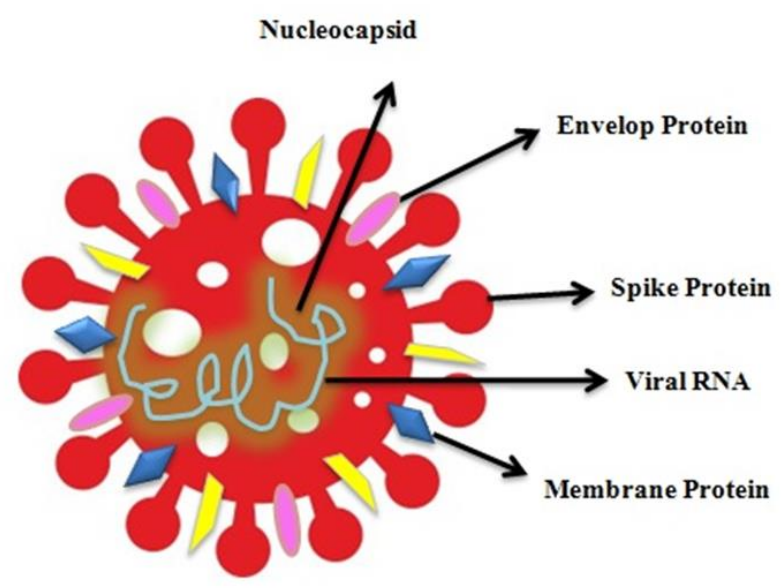

Figure 1. Structure of Coronavirus representing its genome and different proteins

Although the exact mode of transmission of SARS-CoV-2 among humans, its binding capacity and effect on organ damage are still under investigation. Current reports suggested that SARS-CoV-2 interacts with ACE-2 receptors on the target cell through S protein with more than 100 folds to cause viral pathogenicity [14]. The study will take months or years to know the whole overall picture, pathogen characteristics like origin, a symptom of the infection [15]. Based on reports, it is presumed that the natural carriers of Covid-19 are bats, pangolins, 
and snakes. From the study of Peking university, SARS-CoV2 infection is caused by snakes. A study from Wuhan Institute of Virology, bats, are the source of this virus, by Macro genomic sequencing, molecular biological detection, show some similarity that SARS-CoV are isolated from pangolins and virus are infecting humans [16]. Covid-19 virus infection in Respiratory can occur by droplet Spray Contact (direct \& Indirect); airborne transmission [17]; close contact between one person to another person at least 6 feet; and when a person with infection coughs, sneezes, and talks, droplets transmitted to a non-infected person. The transmission can also occur through sweat, stool, urine, and respiratory secretions of infected persons. After monitoring all conditions, the US CDC's given a guideline to maintain social distancing to prevent a virus spread in the community [18]. All age person has a chance of getting infected by these infected viruses. In various studies, it is shown that the loading of viral in the Nasal cavity is high in comparison to the throat in an infected person. The chance of getting an infection is higher through inhaling of droplets or come in contact with contaminated surfaces followed by touching his eyes, nose, mouth [19]. As per reports, these viruses are active on many surfaces for a day in atmospheric conditions, which can be killed by disinfectants like hydrogen peroxide etc. within seconds [20].

\section{Viral Genome, Replication, and Pathogenesis}

SARS-CoV-2 genome comprises five structural proteins, which play an important part in the virus replication cycle, viral assembly, and causing infections. These structure proteins are encoded as Spikes (S) glycoprotein, Membrane (M) glycoprotein, Envelope (E) glycoprotein, Hemagglutin-Esterase (HE), and Nucleoprotein $(\mathrm{N})$. The S-glycoprotein is crucial in making spikes on the viral outer membrane as well as important to adhere to receptors present on host cells. M glycoproteins are glycosylated and are important for virus regeneration in a cell during the RNA replication process. E-glycoprotein is important for virion assembly (envelope) within the cells during replication. N-protein forms the helical viral capsid and forms complex with viral genomic RNA at the ERGIC region where the virus is collected [2123]. HE presents only in some beta corona, but all envelope proteins and $\mathrm{N}$ proteins are present in all virions. S protein is significant for virus arrival into the human host cells. The spike protein segmented in three parts; these three segments are: Ectodermain (ED), TM region, and an intracellular domain, which comprises the intracellular short tail part. The Spike protein consists of two subdomains, namely S1 (receptor binding) domain, and S2 (membrane fusion) domain. Primarily, the interactions occur between S1 domain and host receptors followed by fusion of S2 segment into the host cell, after which the viral membrane allows the release of RNA genome of SARS-CoV-2 inside the host cell. These proteins represent an important target of the drug discovery side. S1 domain: Here, N-Terminal Domain (NTD) and the C-terminal domain, there is the main component of the S1 domain, which acts as a major antigen on the surface of the virus. S1 domain has a receptor-binding domain. S2 subunit: The S2 subunit has two heptad regions (HR1 and 2) and hydrophobic fusion peptide. The replication of SARSCoV-2 takes place within the cytoplasm of the human cell (host), which mainly binds to the surface of the human host cell through the spike protein. Binding to the host receptor brings conformational changes in S-protein, facilitating viral envelope fusion with the membrane of the host cell resulting in the initiation of virus entry into the host cell [24-26].

The virus releases it is a single-stranded and non-segmented RNA genome just after its entry into the cytoplasm of the host cell. The genomic RNA uses Open Reading Frames (ORFs) during the translation process. The genomic RNA 5' terminal encodes for non-structural 
protein like replicase gene. The 2/3rd part of RNA genome is covered by ORF1a/ORF1b and $1 / 3$ rd part utilized for structural and non-essential accessory proteins at 3' terminal. The replicase gene 1 encodes for two ORFs, namely ORF1a/ORF1b, which further translated into two polypeptides ppla and pplb at 5' terminal of RNA genome. Further, these polypeptides (pp1a/pp1b) are cleaved by viral protease into small peptides and form sixteen non-structural proteins (NSP1 to NSP16), which are involved in the formation of a double-membrane vesicle (DMV) of the virion and also important for its replication and transcription. Remaining 1/3rd part of genomic RNA contains 2 to 7 genes, which are translated from sub-genomic RNA (sgRNA) to sub-genomic messenger RNA (sgmRNA). Sub-genomic RNA encodes the structural protein, spike, membrane, nucleocapsid, and the accessories protein for SARS-CoV2. These all viral proteins, RNA genome, are subsequently assembled into virion in ER and release out of the cell [27,28]. Upon entry in the body, viruses attach to the target cell in the human body. The primary target cells are enterocyte (in the gastrointestinal system), Pneumocytes (in lungs), cerebral neuronal cells, and other target cells. Attachment of the virus to target cells takes place via the interaction of S-protein with Angiotensin-Converting Enzyme-2 (ACE-2) receptors present at the host cell surface. Once the receptor recognizes the virus, the viral genome, along with nucleocapsid liberates into the cytoplasm in host cells, the proteins pp1a and pp1b from the viral genes ORF1a and ORF1b use the ribosomes for their own translation process. These ppla and pplb help to form the replication transcription complex and processed by protease and produce 16 Non-Structural Proteins (NSPs), each one has their own specific function [29,30]. NSP1 and NSP2 suppress the host gene expression, NSP3 and NSP5 help to form a multi-domain complex. This multi-domain complex is important for viral replication. NSP4 and NSP6 are considered transmembrane proteins, NSP7 and NSP8 both have similar activity as primase, NSP9 is a dimeric form of RNA binding protein which is responsible for causing viral pathogenicity. NSP10 is a cofactor involved in the activation of a replicative enzyme, NSP12 functions as RNA dependant RNA polymerase (RdRp), NSP13 functions as helicase enzyme, NSP14 exhibits exoribonuclease activity, NSP15 shows endoribonuclease activity, finally, NSP16 is an enzyme having methyltransferase activity. All the NSPs are crucial for the replication and transcription of the viral genome [31-34]. Synthesized protein M, E, S form the structure of the viral envelop, and the replicated genome binds to $\mathrm{N}$ protein and forms ribonucleoprotein complex. Finally, the virus particles come out from the Endoplasmic Reticulum Golgi intermediate Compartment (ERGIC) by making a bud-like structure. These mature virions merge within the plasma membrane by forming a vesicle and release virus particles in the extracellular region. The release of these virions results in a high release of pro-inflammatory cytokines and chemokines, which damage lung tissue and deteriorate its function and, in some cases, can also cause failure [35-37].

\section{WHO Advisory and Recommendations}

On January 30, 2020, WHO Director-General determines the Outbreak of Covid-19 as a health emergency for the public for international concern and provide guidelines for the prevention and control of Covid19 Infections. The guideline is for health care workers, health care managers, IPC team for national and district levels.

$>$ IPC strategies are for prevention and limit transmission in health care: It provides information ensuring triage, early recognition\& source control, applying standard precaution for all patients, implementing addition precaution (droplet, airborne, contact) for a suspected 
case of Covid-19, implementing administrative control, environmental and engineering-related control.

$>$ Collecting and handling laboratory specimens from a patient of Covid-19: It provides information to ensure that HCWs who collect sample use PPE, mask, eye protection, gloves, all personnel who transport sample should have trained to have proper handling, place the sample on leak-proof sample bag (secondary container) that has sealed pockets with patient's name, delivered the sample by hand as possible, do not use pneumatic tube system for transport, the document has the proper name of patient's, date of birth, in the laboratory request form.

$>$ Recommendation for Outpatients cares: It involves hand hygiene, respiratory hygiene, and medical mask use by the patient, early recognition, triage, proper use of contact, droplet precaution for all cases, giving knowledge to the patient and their family about early identification of symptoms, precaution to be used, the symptomatic patient has to wait by ensuring they have a proper separate waiting area.

> Guideline for Quarantine of individual in the context of containment for Covid-19:

Quarantine of patient is a restriction of activity or separation of person who is not ill, but they are exposed to infectious persons by monitoring symptom and ensuring early spotting of cases. The quarantine follows as per the legal framework stated in International Health Regulations 2005. The various norms are given, such as traveling under public health observation (Article 30), measuring health by the entry of travelers (Article 31) information regarding the treatment of traveler (Article 32). WHO has recommended contact of a patient with laboratory confirm Covid-19 be quarantined for 14 days from last time they are exposed to Patients having faceface contact with Covid-19 patient, providing direct care for these patients without carrying personal protective equipment (PPE) properly, come in close contact with Covid-19 patients for some period, traveling with an infected patient in any kind of conveyance, other situation, indicating by local risk assessment.

$>$ Minimum Infection Prevention \& Control Measure: It involves guidelines for early recognition \&control, administrative control, and environmental control [38].

\section{Current treatment strategies}

Currently, there is no specific treatment for COVID-19 infections. Various clinical trials and virtual screening are under process in order to develop a treatment specifically for the Covid-19 pandemic. Since the occurrence of a pandemic, various treatment strategies such as anti-viral drugs and anti-malarial drugs have been used to manage the manifestations in infected patients. However, these are still under the process of clinical trials to develop an authentic treatment strategy in Covid-19 infections. As of now, no specific anti-viral drug proved to be effective against Coronavirus and its associated pathologies. Patients suffering from Covid-19 are symptomatic, some anti-viral drugs like- Remdesivir are used for RNA viruses, and treatment found better results against the patient of Covid-19. Chloroquine found to improve the immunomodulatory effect to combat infection associated with Covid-19. The four most promising candidates, i.e., Chloroquine, Hydroxychloroquine, Remdesivir, Ritonavir/lopinavir, are under investigation (alone or as combination therapy) for the management of Covid-19 infections [39,40]. 


\subsection{USFDA Approved Drugs.}

Remdesivir, an intravenous anti-viral drug, was established to stop up infection with related coronaviruses and even. Ebola, and is also one of the drugs WHO is aiding to research. Based on various reports, this considered effective in inhibiting virulence caused by SARSCoV-2. This anti-viral drug has already been used in some patients with Covid-19 infections in the United States (U.S.), which also appeared to be safe, but again, large experiments are needed to really know if this is the case $[41,42]$.

Lopinavir/Ritonavir: The combination of lopinavir/ritonavir is used in the treatment of viruses like HIV. The combination is also being tested with another anti-viral drug, i.e interferon beta, which proved to be very successful and effective against SARS-CoV-2 infections, developed in-vitro cells and in mice at laboratory levels. Multiple sclerosis is being presently treated with this, and it can furthermore improve the quality of the natural defenses of the body's cells against COVID-19 [43-45].

Chloroquine and hydroxychloroquine, anti-malarial drugs are considered effective in the lab against infections caused by SARS-CoV-2 as it is observed that these drugs prohibit the entry of viruses inside the cells. Chloroquine has been tested in opposition to a large number of dissimilar infections. Both the drugs i.e., chloroquine and hydroxychloroquine are usually indicated in malaria and an autoimmune disease, namely lupus. So far, there are very limited proofs that chloroquine can work for Covid-19, notwithstanding that it has been receiving much boost from Donald Trump (President, United States of America). Nevertheless, large trials are in the process supported by the World Health Organization globally. Chloroquine may exhibit serious side effects in certain people, and it can even lead to the blockage of the immune response, and so it should be discerned in a way to avoid potential problems or dangers [4648] deliberately.

\subsection{Plasma Therapy.}

Plasma therapy or Convalescent plasma therapy is being surveyed in trials suggested working in two different ways. The first treatment strategy is passive immunization, which involves the transfusion of defensive antibodies to the patient at high risk or suffering from Covid-19 infection from those who are not infected as well as those recovered from the Covid19 infection. Based on reports, it is suggested that virulence of novel human Coronavirus can be blocked by "convalescent sera". So far, passive immunization is recommended safe to use. The second treatment approach works by shutting off parts of our own immune system, which leads to a high level of inflammation damaging the lungs. Possible medications must be supplemented to reduce this severity, and utmost care must be taken when handling the immune response. Plasma therapy is considered effective for the disease of infected patients if there is no vaccine and specific drug. In this blood is ejected from patient having or recovered from SARS-CoV-2 infection, followed by separation of plasma serum, which further screened for virus-neutralizing antibodies and transferred to a patient suffering from SARS-CoV-2 infection [49-51]. According to Houston Methodologist, the process takes 1 hour for transferring plasma. In China, a study conducted in 10 adult patients with SARS-CoV-2 infection and a trial dose of $200 \mathrm{ml}$ plasma was transferred, which exhibited improvement, and the virus disappeared from the body without any side effects. In India, Kerala was the first state to conduct this plasma therapy as a nod was given by the Indian Council of Medical Research (ICMR) [52,53]. 


\subsection{Natural Ways to manage SARS-CoV-2 infections.}

As per various advisories issued for the public, the present principle on prevention of Covid-19 is to have body energy to protect from SARS-CoV-2 infections. Studies show that Vitamin $\mathrm{C}$ may prevent or lower the risk of respiratory tract infection in certain conditions. Proper supplement of vitamin D \& vitamin E may decrease resistance to SARS-CoV 2. The main source of increased immunity is to maintain personal hygiene healthy lifestyle, taking nutritional food, fruits. [54] Chinese medicine also has an important role in the management of this infection with a number of traditional medicines. Various studies conducted by the Shanghai Institute of Materia Medica, Chinese Academy of Sciences, and Wuhan Institute of Virology showed many liquids like- chlorogenic acid and baicalin have an inhibitory effect on many viruses and bacteria [55].

\section{On-Going Clinical Trails}

Since Coronavirus is a new disease, there are no approved drugs for its treatment. Because the drug trails generally take a few months to be finished. A drug is marketed as a treatment in US, only after approval from the FDA (U.S. Food \& Drug Administration). Even for Chloroquine/Hydroxychloroquine, US FDA hasn't approved it as a treatment for Coronavirus. Anti-HIV and anti-malarial drugs considered to be potential drugs against Coronavirus but are still under clinical trials in many of the countries (some of those are mentioned in Table 1). There are 351 active clinical trials in which 291 trials have specific against Covid-19 up to April 2, 2020. Out of 291 trials conducted, approx 109 trials suggested pharmacological activity in adult patients against Covid-19 infections. In 109 trials, 82 trials are of interventional studies, 29 placebo-controlled trials [56]. In spite of the fact that special treatments for COVID-19 are yet unknown, drugs are being tested, and clinical trials and are starting to show results. Thus, together with the greater knowledge that scientists are gaining about SARS-CoV-2 will help enormously prior to a vaccine is ready.

Table 1. Various clinical trials conducted using USFDA approved in various countries.

\begin{tabular}{l|l|l|l|l} 
Country & Drug & Target mechanism & $\begin{array}{l}\text { Patients } \\
\text { tested }\end{array}$ & References \\
\hline CHINA & $\begin{array}{l}\text { Chloroquine and } \\
\text { hydroxychloroquine }\end{array}$ & $\begin{array}{l}\text { Decreasing endosomal acidity } \\
\text { inside cells }\end{array}$ & 100 & {$[57]$} \\
\hline FRANCE & $\begin{array}{l}\text { Chloroquine and } \\
\text { hydroxychloroquine }\end{array}$ & $\begin{array}{l}\text { decreasing endosomal acidity } \\
\text { inside cells }\end{array}$ & 48 & {$[58]$} \\
\hline CHINA & Remdesivir & $\begin{array}{l}\text { Nucleotide analog: viral enzyme, } \\
\text { RNA dependant RNA polymerase }\end{array}$ & 308 & {$[59,60]$} \\
\hline USA & Remdesivir & $\begin{array}{l}\text { Nucleotide analog: viral enzyme, } \\
\text { RNA dependant RNA polymerase }\end{array}$ & 1600 & {$[61]$} \\
\hline CHINA & Ritonavir/Lopinavir & $\begin{array}{l}\text { Protease inhibitor, Aspartate } \\
\text { protease inhibitor and inhibits viral } \\
\text { entry to cells }\end{array}$ & 199 & {$[62]$} \\
\hline USA & Favipiravir & $\begin{array}{l}\text { Nucleotide analog: } \\
\text { broad-spectrum inhibitor of viral } \\
\text { RNA polymerase }\end{array}$ & 100 & {$[63]$} \\
\hline CANADA & Liponavir/Ritonavir & $\begin{array}{l}\text { Viral enzyme, RNA dependant } \\
\text { RNA polymerase }\end{array}$ & 1220 & {$[64]$}
\end{tabular}

\section{In-silico Docking Studies}

Since Coronavirus is a new disease and there are few compounds tested for its treatment. Most of the tested compounds are in various stages of clinical trials. Most of the screening has been done using in silico molecular dynamic simulations and virtual screening 
methods. Millions of compounds are exposed to this kind of screening as it is not possible to develop compounds by using in-vitro or in-vivo experimental methods in such a short term [65]. Therefore virtual screening provides the platform for rapid screening of millions of molecules from a large library of compounds. Towards the development of a specific vaccine against Covid-19 treatment, virtual screenings of potential compounds are one of the important concerns [66,67]. Many reports have been published towards finding a suitable molecule against various protein targets in SARS-CoV-2 using in-silico screening and in-vitro methods. Some of these computational studies are mentioned in Table 2.

Table 2. Literature of Drug molecule tested against different targets by various methods.

\begin{tabular}{|c|c|c|c|c|}
\hline Study & Methods & Drug candidate & Mode of action & References \\
\hline $\begin{array}{l}\text { Wang et al. } \\
2020\end{array}$ & In-vitro study & $\begin{array}{l}\text { Chloroquine } \\
\text { Remdesivir }\end{array}$ & $\begin{array}{l}\text { Reduce the viral copy number } \\
\text { of cell supernatant \& viral } \\
\text { infection. }\end{array}$ & {$[40]$} \\
\hline $\begin{array}{l}\text { Shang et al. } \\
2020\end{array}$ & Virtual screening & $\begin{array}{l}\text { Rupintrivir } \\
\text { Lopinavir } \\
\text { Remdesivir } \\
\end{array}$ & $\begin{array}{l}\text { Binding to SARS-CoV-2 } \mathrm{M}^{\mathrm{p} \mathrm{r}} \\
\mathrm{o}\end{array}$ & [68] \\
\hline $\begin{array}{lll}\text { Zhang } & \text { et al. } \\
2020 & & \end{array}$ & In-vitro study & Teicoplanin & $\begin{array}{l}\text { Prevent the entry of SARS- } \\
\text { CoV-2 into the cytoplasm. }\end{array}$ & [69] \\
\hline Jin et al. 2020 & Virtual screening & Ebselen & Binding to SARS-CoV-2 $\mathrm{M}^{\mathrm{p} \mathrm{r}}$ & {$[70]$} \\
\hline Li et al. 2020 & Connectivity map & $\begin{array}{l}\text { Ikarugamycin } \\
\text { Molsidomine }\end{array}$ & $\begin{array}{l}\text { Effective on gene co-expressed } \\
\text { in ACE2 }\end{array}$ & [71] \\
\hline Arya et al. 2020 & Virtual screening & $\begin{array}{l}\text { Formoterol } \\
\text { Chloroqunie }\end{array}$ & $\begin{array}{l}\text { Binding to SARS-CoV-2 } \\
\text { papain-like protease }\end{array}$ & {$[72]$} \\
\hline $\begin{array}{l}\text { Wang et al. } \\
2020\end{array}$ & Virtual screening & $\begin{array}{l}\text { Carfilzomib, } \\
\text { Liponavir, Elbasvir, } \\
\text { Streptomycin }\end{array}$ & $\begin{array}{l}\text { Binding to SARS-CoV-2 } \\
\text { protease enzyme }\end{array}$ & [73] \\
\hline $\begin{array}{l}\text { Sekhar et al. } \\
2020\end{array}$ & Virtual screening & $\begin{array}{l}\text { Beclabuvir, } \\
\text { Saquinavir }\end{array}$ & Binding to SARS-CoV-2 $\mathrm{M}^{\text {pro }}$ & [74] \\
\hline $\begin{array}{l}\text { Wang et al. } \\
2020\end{array}$ & Virtual screening & $\begin{array}{l}\text { Thymopentin, } \\
\text { Saquinavir }\end{array}$ & $\begin{array}{l}\text { Binding to SARS-CoV-2 3C } \\
\text { like proteinase. }\end{array}$ & {$[75]$} \\
\hline $\begin{array}{l}\text { Nowak et al. } \\
2020\end{array}$ & Virtual screening & Lithium & $\begin{array}{l}\text { Reduce apoptosis and inhibit } \\
\text { glycogen synthase kinase } 3 \\
\text { beta. }\end{array}$ & [76] \\
\hline $\begin{array}{lll}\text { Elfiky } & \text { et } & \text { al. } \\
2020 & & \end{array}$ & Virtual screening & $\begin{array}{l}\text { Mycophenolic } \\
\text { Grazoprevir, } \\
\text { Telaprevir }\end{array}$ & $\begin{array}{l}\text { Binding to SARS-CoV-2 } \\
\text { papain-like protease }\end{array}$ & [77] \\
\hline Beck et al. 2020 & MT-DTI & $\begin{array}{l}\text { Atazanavir, } \\
\text { Ritonavir, Efavirenz }\end{array}$ & $\begin{array}{l}\text { Adherence to SARS-CoV-2 3C } \\
\text { like proteinase }\end{array}$ & [78] \\
\hline Chen et al. 2020 & Virtual screening & $\begin{array}{l}\text { Ledipasvir, } \\
\text { Velpatasvir }\end{array}$ & $\begin{array}{l}\text { Binding to SARS-CoV-2 3C } \\
\text { like proteinase }\end{array}$ & [79] \\
\hline
\end{tabular}

\section{Conclusion}

Globally, the greatest challenge of the present scenario is to develop a specific treatment for infection caused by SARS-CoV-2. The international and national authorities are updating the advisories, from time to time, for the prevention of virus transmission among persons as no specific treatment is available to inhibit its virulence factors. Various clinical trials of already available drugs are being tested worldwide in order to develop a vaccine or drug molecule for its treatment, but there are lots of which need to be assured for its clinical safety to decrease the mortality. The rapid way to develop its treatment is the computational screening of approved and new compounds to analyze the potential target interactions and fasten the development process of agents active against SARS-CoV-2 pathogenesis. 


\section{Funding}

This research received no external funding.

\section{Acknowledgments}

Authors are thankful to I.T.S. College of Pharmacy, Ghaziabad, India, for providing us the platform and infrastructure for preparing this manuscript.

\section{Conflicts of Interest}

The authors like to declare that all the authors alone are responsible for the content and writing of the paper. The publication process (peer-review) of the current article is performed under COPE authorship guidelines.

\section{References}

1. Zhou, P.; Yang, X.L.; Wang, X.G.; Hu, B.; Zhang, L.; Zhang, W.; Si, H.R.; Zhu, Y.; Li, B.; Huang, C.L.; Chen, H.D.; Chen, J.; Luo, Y.; Guo, H.; Jiang, R.-D.; Liu, M.Q.; Chen, Y.; Shen, X.R.; Wang, X.; Zheng, X.S.; Zhao, K.; Chen, Q.J.; Deng, F.; Liu, L.L.; Yan, B.; Zhan, F.X.; Wang, Y.Y.; Xiao, G.; Shi, Z.L. Discovery of a novel coronavirus associated with the recent pneumonia outbreak in humans and its potential bat origin. bioRxiv 2020, https://doi.org/10.1101/2020.01.22.914952.

2. World Health Organization. Coronavirus disease 2019(COVID-19) Situation Report-36. https://www.who.int/emergencies/diseases/novel-coronavirus-2019/situation-reports

3. Wu, F.; Zhao, S.; Yu, B.; Chen, Y.M.; Wang, W.; Song, Z.G.; Hu, Y.; Tao, Z.W.; Tian, J.H.; Pei, Y.Y.; Yuan, M.L.; Zhang, Y.L.; Dai, F.H.; Liu, Y.; Wang, Q.M.; Zheng, J.J.; Xu, L.; Holmes, E.C.; Zhang, Y.Z. A new coronavirus associated with human respiratory disease in China. Nature 2020, 579, 265-269, https://doi.org/10.1038/s41586-020-2008-3.

4. Chan-Yeung, M.; Xu, R.H. SARS: epidemiology. Respirology (Carlton, Vic.) 2003, 8 Suppl, S9-14, https://doi.org/10.1046/j.1440-1843.2003.00518.x.

5. Huang, C.; Wang, Y.; Li, X.; Ren, L.; Zhao, J.; Hu, Y.; Zhang, L.; Fan, G.; Xu, J.; Gu, X.; Cheng, Z.; Yu, T.; Xia, J.; Wei, Y.; Wu, W.; Xie, X.; Yin, W.; Li, H.; Liu, M.; Xiao, Y.; Gao, H.; Guo, L.; Xie, J.; Wang, G.; Jiang, R.; Gao, Z.; Jin, Q.; Wang, J.; Cao, B. Clinical features of patients infected with 2019 novel coronavirus in Wuhan, China. The Lancet 2020, 395, 497-506, https://doi.org/10.1016/S01406736(20)30183-5.

6. Singhal, T. A Review of Coronavirus Disease-2019 (COVID-19). The Indian Journal of Pediatrics 2020, 87, 281-286, https://doi.org/10.1007/s12098-020-03263-6.

7. Richman, D.D.; Whitley, R.J.; Hayden, F.G. Clinical Virology. 4th ed. Washington: ASM Press; 2016.

8. Paules, C.I.; Marston, H.D.; Fauci, A.S. Coronavirus Infections-More Than Just the Common Cold. JAMA 2020, 323, 707-708, https://doi.org/10.1001/jama.2020.0757.

9. Chan, J.F.W.; To, K.K.W.; Tse, H.; Jin, D.Y.; Yuen, K.Y. Interspecies transmission and emergence of novel viruses: lessons from bats and birds. Trends in Microbiology 2013, 21, 544-555, https://doi.org/10.1016/j.tim.2013.05.005.

10. Fehr, A.R.; Perlman, S. Coronaviruses: an overview of their replication and pathogenesis. Methods Mol Biol 2015, 1282, 1-23, https://doi.org/10.1007/978-1-4939-2438-7_1.

11. Wu, A.; Peng, Y.; Huang, B.; Ding, X.; Wang, X.; Niu, P.; Meng, J.; Zhu, Z.; Zhang, Z.; Wang, J.; Sheng, J.; Quan, L.; Xia, Z.; Tan, W.; Cheng, G.; Jiang, T. Genome Composition and Divergence of the Novel Coronavirus (2019-nCoV) Originating in China. Cell Host \& Microbe 2020, 27, 325-328, https://doi.org/10.1016/j.chom.2020.02.001.

12. Zhang, S.F.; Tuo, J.L.; Huang, X.B.; Zhu, X.; Zhang, D.M.; Zhou, K.; Yuan, L.; Luo, H.J.; Zheng, B.J.; Yuen, K.Y.; Li, M.F.; Cao, K.Y.; Xu, L. Epidemiology characteristics of human coronaviruses in patients with respiratory infection symptoms and phylogenetic analysis of HCoV-OC43 during 2010-2015 in Guangzhou. PLoS One 2018, 13.

13. Zhu, N.; Zhang, D.; Wang, W.; Li, X.; Yang, B.; Song, J.; Zhao, X.; Huang, B.; Shi, W.; Lu, R.; Niu, P.; Zhan, F.; Ma, X.; Wang, D.; Xu, W.; Wu, G.; Gao, G.F.; Tan, W. A Novel Coronavirus from Patients with Pneumonia in China, 2019. New England Journal of Medicine 2020, 382, 727-733, https://doi.org/10.1056/NEJMoa2001017.

14. Wrapp, D.; Wang, N.; Corbett, K.S.; Goldsmith, J.A.; Hsieh, C.-L.; Abiona, O.; Graham, B.S.; McLellan, J.S. Cryo-EM structure of the 2019-nCoV spike in the prefusion conformation. Science (New York, N.Y.) 2020, 367, 1260-1263, https://doi.org/10.1126/science.abb2507. 
15. Huang, C.; Wang, Y.; Li, X.; Ren, L.; Zhao, J.; Hu, Y.; Zhang, L.; Fan, G.; Xu, J.; Gu, X.; Cheng, Z.; Yu, T.; Xia, J.; Wei, Y.; Wu, W.; Xie, X.; Yin, W.; Li, H.; Liu, M.; Xiao, Y.; Gao, H.; Guo, L.; Xie, J.; Wang, G.; Jiang, R.; Gao, Z.; Jin, Q.; Wang, J.; Cao, B. Clinical features of patients infected with 2019 novel coronavirus in Wuhan, China. The Lancet 2020, 395, 497-506, https://doi.org/10.1016/S01406736(20)30183-5.

16. Ji, W.; Wang, W.; Zhao, X.; Zai, J.; Li, X. Cross-species transmission of the newly identified Coronavirus 2019-nCoV. Journal of Medical Virology 2020, 92, 433-440, https://doi.org/10.1002/jmv.25682.

17. Moriyama, M.; Hugentobler, W.J.; Iwasaki, A. Seasonality of Respiratory Viral Infections. Annual review of virology 2020, 7, 1-2, https://doi.org/10.1146/annurev-virology-012420-022445.

18. https://www.worldometers.info/coronavirus/transmission/

19. World Health Organization. Situation reports. Available at: https:// www.who.int/emergencies/diseases/novel-coronavirus-2019/situation-reports/.Accessed 22 Feb 2020.

20. Kampf, G.; Todt, D.; Pfaender, S.; Steinmann, E. Persistence of coronaviruses on inanimate surfaces and their inactivation with biocidal agents. Journal of Hospital Infection 2020, 104, 246-251, https://doi.org/10.1016/j.jhin.2020.01.022.

21. Hilgenfeld, R. From SARS to MERS: crystallographic studies on coronaviral proteases enable anti-viral drug design. The FEBS Journal 2014, 281, 4085-4096,https://doi.org/10.1111/febs.12936.

22. Li, F. Structure, Function, and Evolution of Coronavirus Spike Proteins. Annual review of virology 2016, 3 , 237-261, https://doi.org/10.1146/annurev-virology-110615-042301.

23. Lin, H.X.; Feng, Y.; Wong, G.; Wang, L.; Li, B.; Zhao, X.; Li, Y.; Smaill, F.; Zhang, C. Identification of residues in the receptor-binding domain (RBD) of the spike protein of human coronavirus NL63 that are critical for the RBD-ACE2 receptor interaction.Journal of general virology2008, 89, 1015-1024, https://doi.org/10.1099/vir.0.83331-0.

24. Oostra, M.; de Haan, C.A.; de Groot, R.J.; Rottier, P.J. Glycosylation of the severe acute respiratory syndrome coronavirus triple-spanning membrane proteins 3a and M. J Virol 2006, 80, 2326-2336, https://doi.org/10.1128/jvi.80.5.2326-2336.2006.

25. Narayanan, K.; Maeda, A.; Maeda, J.; Makino, S. Characterization of the coronavirus M protein and nucleocapsid interaction in infected cells. $J$ Virol 2000, 74, 8127-8134, https://doi.org/10.1128/jvi.74.17.8127-8134.2000.

26. Nieto-Torres, J.L.; Dediego, M.L.; Alvarez, E.; Jiménez-Guardeño, J.M.; Regla-Nava, J.A.; Llorente, M.; Kremer, L.; Shuo, S.; Enjuanes, L. Subcellular location and topology of severe acute respiratory syndrome coronavirus envelope protein. Virology 2011, 415, 69-82, https://doi.org/10.1016/j.virol.2011.03.029.

27. Du, L.; He, Y.; Zhou, Y.; Liu, S.; Zheng, B.-J.; Jiang, S. The spike protein of SARS-CoV — a target for vaccine and therapeutic development. Nature Reviews Microbiology 2009, 7, 226-236, https://doi.org/10.1038/nrmicro2090.

28. Al-Osail, A.M.; Al-Wazzah, M.J. The history and epidemiology of Middle East respiratory syndrome corona virus. Multidisciplinary respiratory medicine 2017, 12, https://doi.org/10.1186/s40248-017-0101-8.

29. Snijder, E.J.; van der Meer, Y.; Zevenhoven-Dobbe, J.; Onderwater, J.J.; van der Meulen, J.; Koerten, H.K.; Mommaas, A.M. Ultrastructure and origin of membrane vesicles associated with the severe acute respiratory syndrome coronavirus replication complex. J Virol 2006, 80, 5927-5940, https://doi.org/10.1128/jvi.0250105.

30. Perlman, S.; Netland, J. Coronaviruses post-SARS: update on replication and pathogenesis. Nature Reviews Microbiology 2009, 7, 439-450, https://doi.org/10.1038/nrmicro2147.

31. Wang, H.; Xue, S.; Yang, H.; Chen, C. Recent progress in the discovery of inhibitors targeting coronavirus proteases. Virologica Sinica 2016, 31, 24-30, https://doi.org/10.1007/s12250-015-3711-3.

32. Imbert, I.; Guillemot, J.-C.; Bourhis, J.-M.; Bussetta, C.; Coutard, B.; Egloff, M.-P.; Ferron, F.; Gorbalenya, A.E.; Canard, B. A second, non-canonical RNA-dependent RNA polymerase in SARS coronavirus. The EMBO journal 2006, 25, 4933-4942, https://doi.org/10.1038/sj.emboj.7601368.

33. Hu, T.; Chen, C.; Li, H.; Dou, Y.; Zhou, M.; Lu, D.; Zong, Q.; Li, Y.; Yang, C.; Zhong, Z.; Singh, N.; Hu, H.; Zhang, R.; Yang, H.; Su, D. Structural basis for dimerization and RNA binding of avian infectious bronchitis virus nsp9. Protein science: a publication of the Protein Society 2017, 26, 1037-1048, https://doi.org/10.1002/pro.3150.

34. Bouvet, M.; Lugari, A.; Posthuma, C.C.; Zevenhoven, J.C.; Bernard, S.; Betzi, S.; Imbert, I.; Canard, B.; Guillemot, J.C.; Lécine, P.; Pfefferle, S.; Drosten, C.; Snijder, E.J.; Decroly, E.; Morelli, X. Coronavirus Nsp10, a critical co-factor for activation of multiple replicative enzymes. J Biol Chem 2014, 289, 2578325796, https://doi.org/10.1074/jbc.M114.577353.

35. Prajapat, M.; Sarma, P.; Shekhar, N.; Avti, P.; Sinha, S.; Kaur, H.; Kumar, S.; Bhattacharyya, A.; Kumar, H.; Bansal, S.; Medhi, B. Drug targets for corona virus: A systematic review. Indian journal of pharmacology 2020, 52, 56-65.

36. Eckerle, L.D.; Becker, M.M.; Halpin, R.A.; Li, K.; Venter, E.; Lu, X.; Scherbakova, S.; Graham, R.L.; Baric, R.S.; Stockwell, T.B.; Spiro, D.J.; Denison, M.R. Infidelity of SARS-CoV Nsp14-exonuclease mutant virus replication is revealed by complete genome sequencing. PLoS Pathog 2010, 6, https://doi.org/10.1371/journal.ppat.1000896. 
37. Ogando, N.S.; Ferron, F.; Decroly, E.; Canard, B.; Posthuma, C.C.; Snijder, E.J. The Curious Case of the Nidovirus Exoribonuclease: Its Role in RNA Synthesis and Replication Fidelity. Front Microbiol 2019, 10, 1813, https://doi.org/10.3389/fmicb.2019.01813.

38. https://www.who.int/emergencies/diseases/novel-coronavirus-2019/technical-guidance

39. Holshue, M.; DeBolt, C.; Lindquist, S.; Lofy, K.; Wiesman, J.; Bruce, H.; Spitters, C.; Ericson, K.; Wilkerson, S.; Tural, A.; Diaz, G.; Cohn, A.; Fox, L.; Patel, A.; Gerber, S.; Kim, L.; Tong, S.; Lu, X.; Lindstrom, S.; Pillai, S. First Case of 2019 Novel Coronavirus in the United States. New England Journal of Medicine 2020, 382, 929-36, https://doi.org/10.1056/NEJMoa2001191.

40. Wang, M.; Cao, R.; Zhang, L.; Yang, X.; Liu, J.; Xu, M.; Shi, Z.; Hu, Z.; Zhong, W.; Xiao, G. Remdesivir and chloroquine effectively inhibit the recently emerged novel coronavirus (2019-nCoV) in vitro. Cell Research 2020, 30, 269-271, https://doi.org/10.1038/s41422-020-0282-0.

41. Al-Tawfiq, J.A.; Al-Homoud, A.H.; Memish, Z.A. Remdesivir as a possible therapeutic option for the COVID-19. Travel Med Infect Dis 2020, 34, https://doi.org/10.1016/j.tmaid.2020.101615.

42. Sheahan, T.P.; Sims, A.C.; Leist, S.R.; Schäfer, A.; Won, J.; Brown, A.J.; Montgomery, S.A.; Hogg, A.; Babusis, D.; Clarke, M.O.; Spahn, J.E.; Bauer, L.; Sellers, S.; Porter, D.; Feng, J.Y.; Cihlar, T.; Jordan, R.; Denison, M.R.; Baric, R.S. Comparative therapeutic efficacy of remdesivir and combination lopinavir, ritonavir, and interferon beta against MERS-CoV. Nature Communications 2020, 11, https://doi.org/10.1038/s41467-019-13940-6.

43. Chu, C.M.; Cheng, V.C.; Hung, I.F.; Wong, M.M.; Chan, K.H.; Chan, K.S.; Kao, R.Y.; Poon, L.L.; Wong, C.L.; Guan, Y.; Peiris, J.S.; Yuen, K.Y. Role of lopinavir/ritonavir in the treatment of SARS: initial virological and clinical findings. Thorax 2004, 59, 252-256, https://doi.org/10.1136/thorax.2003.012658.

44. de Wilde, A.H.; Jochmans, D.; Posthuma, C.C.; Zevenhoven-Dobbe, J.C.; van Nieuwkoop, S.; Bestebroer, T.M.; van den Hoogen, B.G.; Neyts, J.; Snijder, E.J. Screening of an FDA-approved compound library identifies four small-molecule inhibitors of Middle East respiratory syndrome coronavirus replication in cell culture. Antimicrobial agents and chemotherapy 2014, 58, 4875-4884, https://doi.org/10.1128/AAC.03011-14.

45. Lopinavir/ritonavir [database online]. Hudson (OH): Lexicomp Inc; 2016. Accessed March 17, 2020. http://online.lexi.com

46. Colson, P.; Rolain, J.M.; Lagier, J.C.; Brouqui, P.; Raoult, D. Chloroquine and hydroxychloroquine as available weapons to fight COVID-19. Int $J$ Antimicrob Agents 2020, 55, https://doi.org/10.1016/j.ijantimicag.2020.105932.

47. National Health Commission and State Administration of Traditional Chinese Medicine. Diagnosis and treatment protocol for novel coronavirus pneumonia.2020. https://www.chinadaily.com.cn/pdf/2020/1.Clinical.Protocols.for.the.Diagnosis.and.Treatment.o f.COVID-19.V7.pdf

48. Aralen (chloroquine phosphate) [package insert]. Bridgewater, NJ: Sanofi-Aventis; 2008. Accessed March 17, 2020. https://www.accessdata.fda.gov/drugsatfda_docs/label/2018/006002s045lbl.pdf.

49. Bloch, E.M.; Shoham, S.; Casadevall, A.; Sachais, B.S.; Shaz, B.; Winters, J.L.; van Buskirk, C.; Grossman, B.J.; Joyner, M.; Henderson, J.P.; Pekosz, A.; Lau, B.; Wesolowski, A.; Katz, L.; Shan, H.; Auwaerter, P.G.; Thomas, D.; Sullivan, D.J.; Paneth, N.; Gehrie, E.; Spitalnik, S.; Hod, E.A.; Pollack, L.; Nicholson, W.T.; Pirofski, L.A.; Bailey, J.A.; Tobian, A.A. Deployment of convalescent plasma for the prevention and treatment of COVID-19. J Clin Invest 2020, 130, 2757-2765, https://doi.org/10.1172/jci138745.

50. Chen, X.; Tian, J.; Li, G.; Li, G. Initiation of a new infection control system for the COVID-19 outbreak. The Lancet. Infectious diseases 2020, 20, 397-398, https://doi.org/10.1016/s1473-3099(20)30110-9.

51. Duan, K.; Liu, B.; Li, C.; Zhang, H.; Yu, T.; Qu, J.; Zhou, M.; Chen, L.; Meng, S.; Hu, Y.; Peng, C.; Yuan, M.; Huang, J.; Wang, Z.; Yu, J.; Gao, X.; Wang, D.; Yu, X.; Li, L.; Zhang, J.; Wu, X.; Li, B.; Xu, Y.; Chen, W.; Peng, Y.; Hu, Y.; Lin, L.; Liu, X.; Huang, S.; Zhou, Z.; Zhang, L.; Wang, Y.; Zhang, Z.; Deng, K.; Xia, Z.; Gong, Q.; Zhang, W.; Zheng, X.; Liu, Y.; Yang, H.; Zhou, D.; Yu, D.; Hou, J.; Shi, Z.; Chen, S.; Chen, Z.; Zhang, X.; Yang, X. Effectiveness of convalescent plasma therapy in severe COVID-19 patients. Proceedings of the National Academy of Sciences 2020, 117, 9490-9496, https://doi.org/10.1073/pnas.2004168117.

52. Teixeira da Silva, J.A. Convalescent plasma: A possible treatment of COVID-19 in India. Medical Journal Armed Forces India 2020, 76, 236-237, https://doi.org/10.1016/j.mjafi.2020.04.006.

53. Science and technology efforts in India on Covid-19. Vigyan Prasar, an autonomous organization of DST, Government of India. Updated regularly dated 17-04-2020. https://www.nccs.res.in/uploads//COVID19.pdf

54. Hemilä, H. Vitamin C intake and susceptibility to pneumonia. The Pediatric infectious disease journal 1997, 16, 836-837, https://doi.org/10.1097/00006454-199709000-00003.

55. Li, W. The curative effect observation of shuanghuanglian and penicillin on acute tonsillitis. Lin chuang er bi yan hou ke za zhi = Journal of clinical otorhinolaryngology 2002, 16, 475-476.

56. Sanders, J.M.; Monogue, M.L.; Jodlowski, T.Z.; Cutrell, J.B. Pharmacologic Treatments for Coronavirus Disease 2019 (COVID-19): A Review. JAMA 2020, 323, 1824-1836, https://doi.org/10.1001/jama.2020.6019. 
57. Gao, J.; Tian, Z.; Yang, X. Breakthrough: Chloroquine phosphate has shown apparent efficacy in treatment of COVID-19 associated pneumonia in clinical studies. Biosci Trends 2020, 14, 72-73, https://doi.org/10.5582/bst.2020.01047.

58. Gautret, P.; Lagier, J.C.; Parola, P.; Hoang, V.T.; Meddeb, L.; Mailhe, M.; Doudier, B.; Courjon, J.; Giordanengo, V.; Vieira, V.E.; Dupont, H.T.; Honoré, S.; Colson, P.; Chabrière, E.; La Scola, B.; Rolain, J.M.; Brouqui, P.; Raoult, D. Hydroxychloroquine and azithromycin as a treatment of COVID-19: results of an open-label non-randomized clinical trial. Int $J$ Antimicrob Agents 2020, https://doi.org/10.1016/j.ijantimicag.2020.105949.

59. Cao, B. China-Japan Friendship. Hospital, https://clinicaltrials.gov/ct2/show/NCT04252664

60. Holshue, M.L.; DeBolt, C.; Lindquist, S.; Lofy, K.H.; Wiesman, J.; Bruce, H.; Spitters, C.; Ericson, K.; Wilkerson, S.; Tural, A.; Diaz, G.; Cohn, A.; Fox, L.; Patel, A.; Gerber, S.I.; Kim, L.; Tong, S.; Lu, X.; Lindstrom, S.; Pallansch, M.A.; Weldon, W.C.; Biggs, H.M.; Uyeki, T.M.; Pillai, S.K. First Case of 2019 Novel Coronavirus in the United States. $N$ Engl J Med 2020, 382, 929-936, https://doi.org/10.1056/NEJMoa2001191.

61. Gilead Sciences https://clinicaltrials.gov/ct2/show/NCT04292730

62. Cao, B.; Wang, Y.; Wen, D.; Liu, W.; Wang, J.; Fan, G.; Ruan, L.; Song, B.; Cai, Y.; Wei, M.; Li, X.; Xia, J.; Chen, N.; Xiang, J.; Yu, T.; Bai, T.; Xie, X.; Zhang, L.; Li, C.; Yuan, Y.; Chen, H.; Li, H.; Huang, H.; Tu, S.; Gong, F.; Liu, Y.; Wei, Y.; Dong, C.; Zhou, F.; Gu, X.; Xu, J.; Liu, Z.; Zhang, Y.; Li, H.; Shang, L.; Wang, K.; Li, K.; Zhou, X.; Dong, X.; Qu, Z.; Lu, S.; Hu, X.; Ruan, S.; Luo, S.; Wu, J.; Peng, L.; Cheng, F.; Pan, L.; Zou, J.; Jia, C.; Wang, J.; Liu, X.; Wang, S.; Wu, X.; Ge, Q.; He, J.; Zhan, H.; Qiu, F.; Guo, L.; Huang, C.; Jaki, T.; Hayden, F.G.; Horby, P.W.; Zhang, D.; Wang, C. A Trial of Lopinavir-Ritonavir in Adults Hospitalized with Severe Covid-19. New England Journal of Medicine 2020, 382, 1787-1799, https://doi.org/10.1056/NEJMoa2001282.

63. https://clinicaltrials.gov/ct2/show/NCT04336904? cond=COVID-19\&draw=2\&rank=2

64. https://clinicaltrials.gov/ct2/show/NCT04321174

65. Zhang, L.; Liu, Y. Potential interventions for novel Coronavirus in China: A systematic review. J Med Virol 2020, 92, 479-490, https://doi.org/10.1002/jmv.25707.

66. Jamkhande, P.G.; Ghante, M.H.; Ajgunde, B.R. Software based approaches for drug designing and development: A systematic review on commonly used software and its applications. Bulletin of Faculty of Pharmacy, Cairo University 2017, 55, 203-210, https://doi.org/10.1016/j.bfopcu.2017.10.001.

67. Gioia, D.; Bertazzo, M.; Recanatini, M.; Masetti, M.; Cavalli, A. Dynamic Docking: A Paradigm Shift in Computational Drug Discovery. Molecules 2017, 22, https://doi.org/10.3390/molecules22112029.

68. Ton, A.T.; Gentile, F.; Hsing, M.; Ban, F.; Cherkasov, A. Rapid Identification of Potential Inhibitors of SARS-CoV-2 Main Protease by Deep Docking of 1.3 Billion Compounds. Molecular Informatics 2020, https://doi.org/10.1002/minf.202000028.

69. Zhang, J.; Ma, X.; Yu, F.; Liu, J.; Zou, F.; Pan, T.; Zhang, H. Teicoplanin potently blocks the cell entry of 2019-nCoV. bioRxiv 2020, https://doi.org/10.1101/2020.02.05.935387.

70. Jin, Z.; Du, X.; Xu, Y.; Deng, Y.; Liu, M.; Zhao, Y.; Zhang, B.; Li, X.; Zhang, L.; Duan, Y.; Yu, J.; Wang, L.; Yang, K.; Liu, F.; You, T.; Liu, X.; Yang, X.; Bai, F.; Liu, H.; Liu, X.; Guddat, L.W.; Xiao, G.; Qin, C.; Shi, Z.; Jiang, H.; Rao, Z.; Yang, H. Structure-based drug design, virtual screening and high-throughput screening rapidly identify anti-viral leads targeting COVID-19. bioRxiv 2020, https://doi.org/10.1101/2020.02.26.964882.

71. Li, Z.; Bai, T.; Yang, L.; Hou, X. Discovery of potential drugs for COVID-19 based on the connectivity map.2020; https://doi.org/10.21203/rs.2.24684/v1.

72. Rimanshee, A.; Amit, D.; Vishal, P.; Mukesh, K. Potential inhibitors against papain-like protease of novel $\begin{array}{lllll}\text { coronavirus (SARS-CoV-2) from } & \text { FDA }\end{array}$ https://doi.org/10.26434/chemrxiv.11860011.v2.

73. Wang, J. Fast Identification of Possible Drug Treatment of Coronavirus Disease-19 (COVID-19) through Computational Drug Repurposing Study. J Chem Inf Model 2020, 60, 3277-3286, https://doi.org/10.1021/acs.jcim.0c00179.

74. Talluri, S. Virtual Screening Based Prediction of Potential Drugs for COVID-19. 2020; https://doi.org/10.20944/preprints202002.0418.v2.

75. Wang, Q.; Zhao, Y.; Chen, X.; Hong, A. Virtual Screening of Approved Clinic Drugs with Main Protease $\left(3 \mathrm{CL}^{\text {pro }}\right)$ Reveals Potential Inhibitory Effects on SARS-CoV-2. Preprints 2020.

76. Nowak, J.; Walkowiak, J. Is lithium a potential treatment for the novel Wuhan (2019-nCoV) Coronavirus? A scoping review. F1000Research 2020, 9, https://doi.org/10.12688/f1000research.22299.1.

77. Elfiky, A.; Samir, N. Anti-SARS and anti-HCV drugs repurposing against the Papain-like protease of the newly emerged Coronavirus (2019-nCoV). 2020; https://doi.org/10.21203/rs.2.23280/v1.

78. Beck, B.R.; Shin, B.; Choi, Y.; Park, S.; Kang, K. Predicting commercially available anti-viral drugs that may act on the novel coronavirus (SARS-CoV-2) through a drug-target interaction deep learning model. Computational and structural biotechnology journal $\mathbf{2 0 2 0}, \quad 18, \quad 784-790$, https://doi.org/10.1016/j.csbj.2020.03.025. 
79. Yu Wai, C.; Chin-Pang, Y.; Kwok-Yin, W. Prediction of the 2019-nCoV 3C-like Protease (3CLpro) Structure: Virtual Screening Reveals Velpatasvir, Ledipasvir, and Other Drug Repurposing Candidates. 2020; https://doi.org/10.26434/chemrxiv.11831103.v1. 